\title{
Influence of habitat confluence on aquatic microbial assemblages in experimental mesocosms
}

\author{
Julia M. Brown, Nicola R. Felice, Nicholas B. Scalfone, Ian Hewson* \\ Department of Microbiology, Cornell University, Wing Hall 403, Ithaca, New York 14853, USA
}

\begin{abstract}
Bacterioplankton assemblages play crucial ecosystem roles in diverse aquatic habitats. Areas in which 2 distinct aquatic bodies converge provide insight into how bacterial communities respond to dramatic environmental change and assemblage confluence. The tolerance and success of combined assemblage components to mixed conditions, however, is unclear. To address this, freshwater (FW) and seawater (SW) were combined in ratios of entirely SW, 1:10, 1:1, 10:1 and entirely FW in experimental mesocosms on Appledore Island, Gulf of Maine (Shoals Marine Laboratory), to examine the response of microbial abundance and composition to habitat convergence. The relative proportion of operational taxonomic units (OTUs) that increased in each incubation demonstrated that SW OTUs were more capable of success in FW habitats than FW OTUs in SW habitats. Most OTUs from each source that grew under confluent conditions were initially rare $(<1 \%$ of the total fingerprint amplified fluorescence) in the incubations. These data demonstrate that rarer OTUs may be more responsive to environmental change than abundant OTUs. These data ultimately indicate that habitat confluence imparts changes in microbial assemblages and that mixing zones within areas of habitat confluence (e.g. estuaries and intertidal rock pools) select for new assemblages composed of OTUs that may be adapted to mixed conditions and that are at low abundance in source populations.
\end{abstract}

KEY WORDS: Microbial community $\cdot$ Mixing $\cdot$ Dispersal $\cdot$ Marine $\cdot$ Operational taxonomic unit · ARISA · Gulf of Maine

\section{INTRODUCTION}

The study of areas in which saltwater and freshwater systems converge is useful for determining what factors influence the structure of microbial communities and how the communities reshape in response to rapid environmental change. Aquatic microbial assemblages are important for the biogeochemistry and ecology of aquatic ecosystems by processing dissolved and particulate organic matter through the microbial loop (Pomeroy 1974, Azam et al. 1983, Ducklow 1983). Despite the overall importance of bacteria across aquatic habitats, the composition of bacterial assemblages in freshwater and saltwater ecosystems is different (for a review, see Logares et al. 2009). Comparison of $16 \mathrm{~S}$ rRNA libraries of microbial communities from different aquatic ecosystems reveals a strong clustering of communities from saltwater locations away from freshwater communities, suggesting that salinity is a major determinant of community composition (Lozupone \& Knight 2007). Metagenome sequence libraries reflect similar trends, with freshwater libraries appearing distinct from saltwater libraries (Rusch et al. 2007). Even on the level of individual bacterial groups, such as the alphaproteobacterial SAR11 cluster, these groups recovered from marine, brackish and freshwater systems are separated into distinct clades (Zwart et al. 1998, Kan et al. 2008). In addition, phylogenetic groups are more common in one system compared to the other - such is the case with the Betaproteobacteria, which are much more dominant in freshwater systems than marine systems (Methe et al. 1998, Bouvier $\&$ del Giorgio 2002). These differences suggest that 
over evolutionary timescales, the transition between saltwater and freshwater requires extensive physiological adaptation, and successful transitions are rare events (Logares et al. 2009).

How bacterial communities change through zones of habitat confluence is a common question in microbial ecology. The transition from salt- to freshwater ecosystems is accompanied by specific factors that may influence changes in community composition. These factors include salinity changes (Oren 2001, Logares et al. 2009), introduction of new predators (Lebaron et al. 2001, Bonilla-Findji et al. 2009), competition within converging communities (Logares et al. 2009) and changes in the availability of inorganic and organic nutrients (Cottrell \& Kirchman 2000, Bouvier \& del Giorgio 2002, Torsvik et al. 2002). Several studies have observed changes in microbial community structure that mirror the sharp changes in biogeochemistry along estuarine gradients (Bouvier \& del Giorgio 2002, Herlemann et al. 2011). For example, the prevalence of Betaproteobacteria correlated with DOM concentration, although it was noted that all biogeochemical measurements covaried closely with changes in salinity (Bouvier \& del
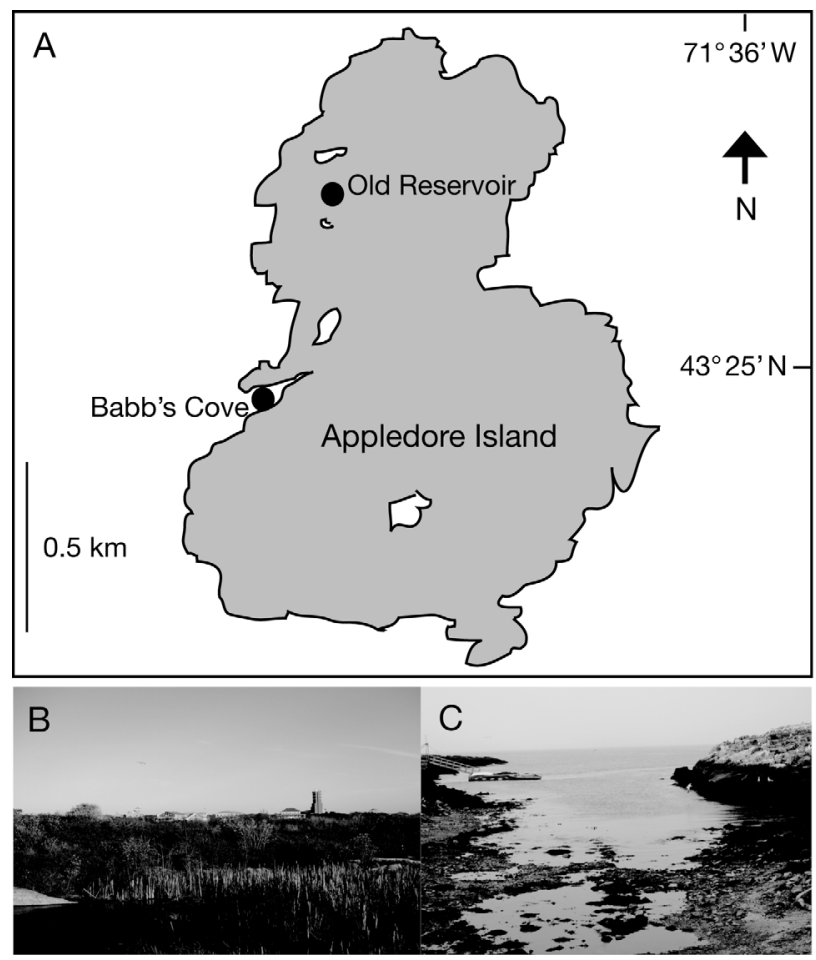

Fig. 1. (A) Map of Appledore Island $\left(42^{\circ} 59^{\prime} 17^{\prime} \mathrm{N}\right.$, $\left.70^{\circ} 36^{\prime} 52^{\prime} \mathrm{W}\right)$ showing sampling locations in Old Reservoir (freshwater) and Bab's Cove (seawater) used in preparation of experimental mesocosms; (B) photograph of Old Reservoir and (C) photograph of Bab's Cove
Giorgio 2002). A later study found that longer residence times in an estuary of the Gulf of Maine in the summer and fall allowed a unique estuarine microbial community to develop (Crump et al. 2004), consistent with observations within the Baltic Sea (Andersson et al. 2010). Several studies have observed distinct microbial communities in the marine and freshwater portions of estuaries (Bouvier \& del Giorgio 2002, Crump et al. 2004, Herlemann et al. 2011), where typically freshwater bacteria may be present in saltwater assemblages (Kisand et al. 2005, Riemann et al. 2008).

The aim of this study was to examine the impacts of habitat confluence on microbial assemblage structure over time in experimental mesocosms. We used tannin-rich freshwater pools and adjacent marine waters as endmembers for mesocosms under mixed water conditions.

\section{MATERIALS AND METHODS}

\section{Sampling location}

Appledore Island (Isles of Shoals, Maine, USA) has ca. 1000 supratidal ponds, including 3 larger freshwater habitats that serve as freshwater sources on the fresh to marine spectrum (J. Simonis unpubl. data; Fig. 1). Seawater and freshwater were collected on Appledore Island, adjacent to the Shoals Marine Laboratory, in June 2009. Seawater was collected in an acid-washed and seawater rinsed carboy (20 l) from Babs Cove, a small inlet that at the site of sampling is $\sim 2.5 \mathrm{~m}$ deep at mean low water. The tidal range in the cove is $\sim 3 \mathrm{~m}$. The salinity at the time of sampling was $\sim 30$ ppt. Freshwater was collected from Old Reservoir (Fig. 1), a small tannic impoundment on the northern side of the island, which has a maximum depth of $\sim 1 \mathrm{~m}$. Old Reservoir water was collected into an acid-washed and sample-rinsed 201 cubitainer.

\section{Experimental setup}

Unfiltered seawater (SW) and freshwater (FW) was mixed in ratios of 10:1, 1:1 or 1:10 FW:SW, with entirely SW and entirely FW incubations as endmember (i.e. source water) controls. The mesocosms were run in duplicate within 41 cubitainers that were acidwashed and sample-rinsed before the start of the experiment. The incubations were maintained at seawater temperature $\left(\sim 15^{\circ} \mathrm{C}\right.$; which was similar to 
freshwater temperature) in flow-through outdoor aquaria and kept under a neutral-density shadecloth ( $25 \%$ light attenuation). The incubations were sampled after 0 (T1), 5 (T5) and 7 d (T7) for bacterial composition via automated rRNA intergenic spacer analysis (ARISA), after 0, 1 and $7 \mathrm{~d}$ for bacterial and archaeal abundance by epifluorescence microscopy with 4',6-diamidino-2-phenylindole (DAPI) staining and after $0,1,5$ and $7 \mathrm{~d}$ for chlorophyll $a(\mathrm{chl} a)$ concentration via acetone-extracted spectrophotometry. For bacterial composition assessments, $400 \mathrm{ml}$ of incubation water was decanted from incubations at each time point and filtered through $1 \mu \mathrm{m}$ polycarbonate (Nuclepore) and $0.2 \mu \mathrm{m}$ Durapore filters $(25 \mathrm{~mm}$ diameter) using positive pressure filtration driven by a peristaltic pump. The $0.2 \mu \mathrm{m}$ filter was removed from filter holders and placed into sterile microcentrifuge tubes, which were then immediately frozen on liquid $\mathrm{N}_{2}$. For chl a analyses, 150 to $500 \mathrm{ml}$ of incubation were filtered through $25 \mathrm{~mm}$ GF/F filters (Whatman), which were placed into foil packets and frozen at $-20^{\circ} \mathrm{C}$ until later pigment extraction and quantification. A single sample from each replicate incubation was prepared for chl a analysis. Bacterioplankton (Bacteria and Archaea) abundance samples consisted of $15 \mathrm{ml}$ of incubation samples, which were amended with $2 \%$ formalin and kept at $4^{\circ} \mathrm{C}$ in a refrigerator until processing for microscopic enumeration (within $6 \mathrm{~h}$ of collection).

\section{Bacterial enumeration}

Bacterioplankton were enumerated by DAPI staining and epifluorescence microscopy (Porter \& Feig 1980). Samples (2 ml) were first stained for $2 \mathrm{~min}$ with DAPI ( $1 \mathrm{mg} \mathrm{ml}^{-1}$ ) and then filtered through $0.22 \mu \mathrm{m}$ black Isopore (Millipore) polycarbonate filters. The filters were then placed on a glass slide, to which $30 \mu \mathrm{l}$ immersion oil was added, and covered with a coverslip. Slides were frozen prior to bacterial enumeration at Cornell University. Duplicate slides from each incubation were counted under UV excitation on an Olympus BX-51 epifluorescence microscope. More than 200 cells were counted on each slide in 20 fields.

\section{Chl a analysis}

Samples for chl a analysis were thawed and amended with $10 \mathrm{ml}$ of acetone (90\%) in polypropylene centrifuge tubes and allowed to extract at $-20^{\circ} \mathrm{C}$ in the dark overnight. The tubes were cen- trifuged at $3000 \times g$ for 5 min to pellet filter materials before spectrophotometry. The spectral qualities of extracted pigments in the acetone fraction were measured on a Spectronic 20 (Turner Designs) spectrophotometer at 630,647, 664 and $750 \mathrm{~nm}$, after which the samples were acidified by addition of 1 drop of $10 \% \mathrm{HCl}$ and were then re-analyzed at 664 and $750 \mathrm{~nm}$. Chl a concentration was calculated according to previously described methods (Parsons et al. 1985).

\section{Automated rRNA intergenic spacer analysis}

DNA from filters intended for analysis of bacterial and archaeal assemblages were extracted using a Zymo Soil Mini kit according to the manufacturer's instructions. We chose this extraction kit because it effectively removes PCR inhibitors (tannins were visible in freshwater) that would have interfered with downstream analyses. The composition of bacterioplankton assemblages was assessed using automated rRNA intergenic spacer analysis (ARISA) (Fisher \& Triplett 1999), following modifications of Hewson \& Fuhrman (2004). Briefly, 10 ng of extracted DNA from each sample was used as a template in the PCR reactions. Each $50 \mu$ l reaction contained $1 \times$ PCR Buffer, $2.5 \mathrm{mM} \mathrm{MgCl}_{2}, 1 \mathrm{mM}$ dNTPs (Promega nucleotide mix), 10 pmol each of primers $1392 \mathrm{~F}$ and 23S-125R-TET (labeled with a 5'-TET

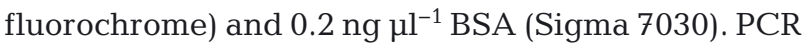
reaction mixes underwent a 5 min heating step at $94^{\circ} \mathrm{C}$, followed by 30 cycles of denaturing $\left(94^{\circ} \mathrm{C}\right.$ for $30 \mathrm{~s})$, annealing $\left(55^{\circ} \mathrm{C}\right.$ for $\left.30 \mathrm{~s}\right)$ and extension $\left(71^{\circ} \mathrm{C}\right.$ for $45 \mathrm{~s}$ ), and following the thermal cycling, a final extension step was conducted at $71^{\circ} \mathrm{C}$ for $7 \mathrm{~min}$. PCR reactions were purified using Zymo Clean \& Concentrator-5 columns, following the manufacturer's recommendations to remove salts and unincorporated nucleotides, and eluted in $10 \mu$ of nuclease-free water. Purified amplified DNA was quantified using PicoGreen fluorescence and diluted to $35 \mathrm{ng}^{-1}$. The products were run on an ABI 377XL capillary sequencer for $4.5 \mathrm{~h}$ at $6 \mathrm{~V}$, using a custom-made ROXlabeled size standard that contained fragments every 50 base pairs (bp) from 200 to 1200 bp (Bioventures).

\section{Community fingerprint analysis}

Outputs from fragment analysis were interrogated using the Peak Scanner 1.0 program (Applied Biosystems). Outputs of relative fluorescence intensity and 
size were extracted. ARISA assemblage fingerprints were analyzed according to protocols reported by Hewson \& Fuhrman (2006a), following the shifting bin-window technique. Peaks $<0.1 \%$ of total amplified DNA fluorescence and peaks $<400$ and $>1200 \mathrm{bp}$ were discarded before binning \pm 3 bp from 400 to $700 \mathrm{bp}, \pm 5 \mathrm{bp}$ from 700 to $1000 \mathrm{bp}$ and $\pm 10 \mathrm{bp}$ from 1000 to $1200 \mathrm{bp}$ (Hewson \& Fuhrman 2004). The Whittaker index and Jaccard index were calculated as maxima between 10 bin frames using the XLStat plugin in Microsoft Excel. Agglomerative hierarchical clustering was performed on the matrices of maximum Whittaker and Jaccard indices.

\section{RESULTS AND DISCUSSION}

Our data demonstrate that habitat confluence in experimental mesocosms results in changes to the abundance and composition of microbial communi-
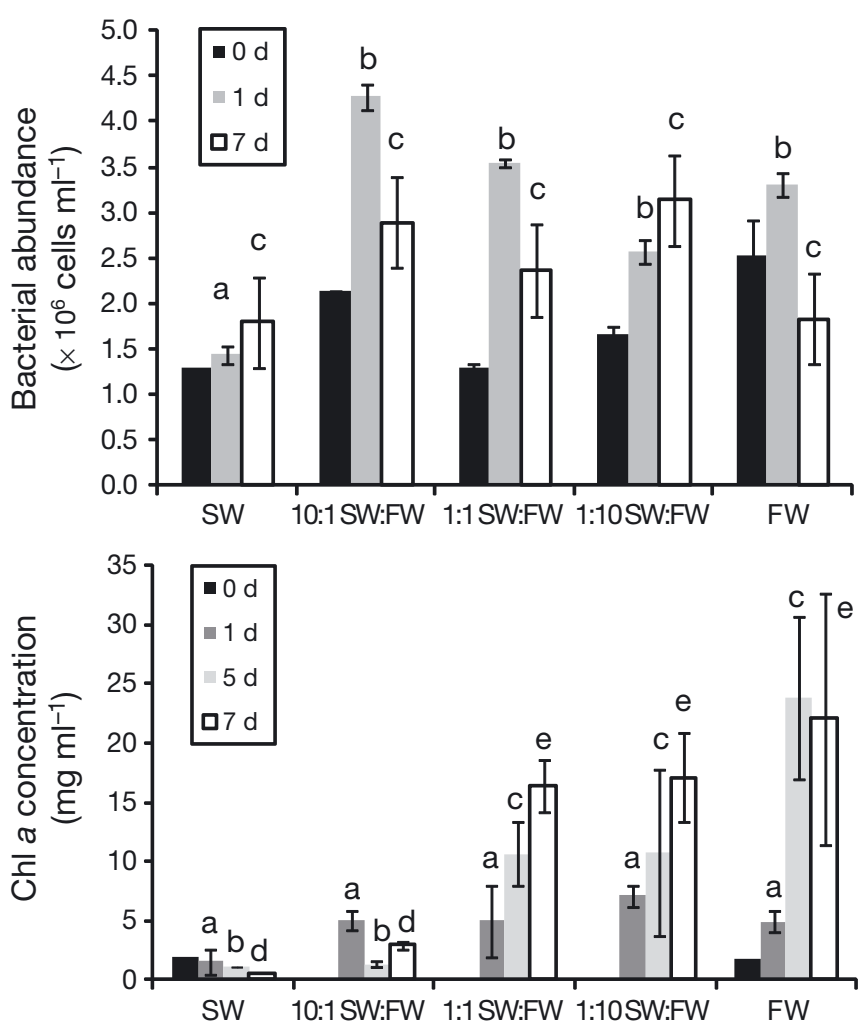

Fig. 2. (a) Bacterial abundance as measured using DAPI staining (Porter \& Feig 1980) and (b) chlorophyll a (chl a) as measured using acetone-extracted spectrophotometry in experimental incubations over time. FW: freshwater; SW: seawater. Error bars $=\mathrm{SE}$ of replicate incubations $(\mathrm{n}=2)$. Letters above bars indicate significant $(p<0.05$, Student's $t$-test) differences between treatments within each timepoint (for timepoints 1, 5, and $7 \mathrm{~d}$ ) ties. These impacts, however, are not the same among constitutive assemblage components. Our data provide evidence that when seawater is mixed with a large proportion of freshwater, bacterial OTUs from seawater may be stimulated in relative abundance, while freshwater OTUs did not respond as such when mixed in higher proportion with seawater. Under equal mixing scenarios, more seawater bacterial OTUs were stimulated than freshwater OTUs.

\section{Microbial abundance and biomass}

Across incubations, bacterial abundance was greatest initially in freshwaters and least in seawater (Fig. 2). Interestingly, the abundance of bacteria was the same in the 1:1 SW:FW as in the SW-only incubation initially, which may be due to osmotic stress imposed on freshwater bacteria by the addition of salty water. Osmotic stress may cause freshwater cells to burst; hence, they would not appear in microscope counts. The highest bacterial abundance occurred after $1 \mathrm{~d}$ in the 10:1 SW:FW incubations. Several incubations experienced sharp increases in bacterial abundance over the first $2 \mathrm{~d}$ of the experiment followed by declines, notably the 1:1 SW:FW and the 10:1 SW:FW incubations. After $1 \mathrm{~d}$, all of the incubations containing freshwater had significantly higher abundances than the SW incubation $(\mathrm{p}<0.05$, Student's $t$-test for all pairwise comparisons to SW). Of the incubations containing FW, the 1:10 SW:FW incubation was significantly lower than other incubations after $1 \mathrm{~d}(\mathrm{p}<0.05$, Student's $t$-test for all pairwise comparisons to 1:10 SW:FW). After $7 \mathrm{~d}$ of incubation, there were no significant differences among the incubations.

Initial chl a levels were the same for FW and SW. Mesocosms containing $>50 \% \mathrm{FW}$ had increased phytoplankton biomass over time based upon chl a concentration, while chl a concentration in mesocosms with $<50 \% \mathrm{FW}$ decreased gradually over time. Significant differences $(\mathrm{p}<0.05$, Student's $t$-test $)$ between chl $a$ levels at 5 and $7 \mathrm{~d}$ were seen in incubations containing $>50 \%$ SW.

Bacterioplankton abundance is generally higher in freshwater than in seawater, primarily because of the large concentration of dissolved organic C (DOC) in freshwater (Maranger \& Bird 1995). The freshwater used in this experiment was a deep brown color, presumably due to humic materials leached from surrounding soils and vegetation (i.e. allochthonous DOC). It is interesting to note that the large increase 
in chl a concentration in FW-only incubations did not correspond to elevated bacterial abundance, suggesting that autochthonous DOC inputs are no more labile than allochthonous DOC. However, this may also be due a larger abundance of particle-attached bacteria, which were not included in our analysis because the samples for nucleic acids were prefiltered to remove particles and larger eukaryotes. The large increases in bacterial abundance in incubations containing $\geq 50 \%$ SW suggests that FWallochthonous DOC is more labile to marine taxa than their freshwater counterparts, consistent with the findings of Stepanauskas et al. (2003). This finding also supports the observations of RochelleNewall et al. (2004) and Bonilla-Findji et al. (2009), whose results indicated that parts of terrestrial DOC are labile to marine bacteria.

\section{Comparison of rare and more highly represented OTU dynamics}

To examine the OTUs that were stimulated by habitat confluence, OTUs that had ratios of T7:T5 and T5:T1 $>1$ were compared to a list of OTUs that were stimulated in either SW- or FW-only treatments. Matching OTUs were discarded from further analyses (i.e. they were defined as stimulated by containment). The mean contribution to ARISA fingerprint fluorescence of increasing OTUs was $1.46 \pm 0.89$ ( $\mathrm{n}=$ $7)$ in the 10:1 SW:FW incubations, $0.10 \pm 0.02(\mathrm{n}=13)$ in the 1:1 SW:FW incubations and $0.34 \pm 0.14(\mathrm{n}=17)$ in the 1:10 SW:FW incubations. Of all stimulated OTUs, only one was shared between treatments; however, we acknowledge that others may have been present below the ARISA detection threshold of $0.1 \%$ in the other incubations. Only 3 OTUs contributing $>1 \%$ of the total amplified DNA to T1 fingerprints were among the 36 OTUs across all incubations that increased over the course of the experiment in response to treatment.

Our data demonstrate that most bacterial OTUs that are capable of responding rapidly to habitat confluence are rarer taxa. Bacterial communities across a range of habitats are typically dominated by few dominant taxa, with a long tail of rarer taxa in species distribution curves (Giovannoni \& Stingl 2005). Abundant taxa in seawater are believed to be mostly k-selected organisms (Morris et al. 2002), while rarer components of assemblages are believed to be r-selected and capable of rapid response to prevailing conditions (Lamy et al. 2009). Hence, our data support that rarer organisms within communities are capable of exploiting the new conditions when habitats are confluent. In addition, the emergence of rare taxa over time within these incubations supports previous findings that a unique brackish community exists when marine and freshwater meet over longer residence times (Crump et al. 2004).

Of the 34 OTUs that increased in relative proportion under confluence, 25 were more highly represented in initial SW fingerprints, while only 9 were more highly represented in FW fingerprints. Notably, of the OTUs that increased in the 1:10 SW:FW treatment, 12 were more highly represented in initial SW fingerprints, and only 5 were more highly represented in FW fingerprints. All of the SW OTUs that increased in the 1:10 SW:FW treatment composed $<0.5 \%$ of the initial fingerprints for that treatment. These data indicate that rare seawater OTUs may be more capable of utilizing the allochthonous DOC introduced into SW than freshwater OTUs in mostly SW habitats. Alternatively, mixing may stimulate OTUs that are adapted to brackish conditions that are present at low levels in the SW inoculum. Because seawater taxa may experience a wide range of salinity in coastal zones, there may be a wider suite of taxa adapted to mixed habitat conditions than freshwater bacteria, which do not experience variable salinity under ambient conditions (Logares et al. 2009).

\section{Habitat confluence}

Our data provide evidence that microbial assemblages are responsive to confluence and that assemblages receiving a greater proportion of inoculum from one habitat with respect to another may converge in the assemblage structure of that habitat. Assemblage ARISA fingerprints clustered together similarly using both the Whittaker and Jaccard indices ( $\mathrm{p}<0.001$, Mantel test, $\mathrm{r}=0.58)$, while the mean similarity between all fingerprints was lower based on the Jaccard index than the Whittaker index (data not shown). Clustering using non-metric multidimensional scaling revealed that the fingerprints grouped based on SW and FW composition (Fig. 3). The least change (indicated by the length of arrows on Fig. 3) between sampling times occurred in the $100 \%$ SW incubations, and the greatest variation between sampling times occurred in the incubations containing $\geq 50 \% \mathrm{FW}$. Incubations containing $50 \%$ FW and $50 \%$ SW initially were more similar to incubations containing $>50 \%$ SW, but after 5 d were more similar to $>50 \%$ FW incubations. The clustering of predominately FW assemblages away from 


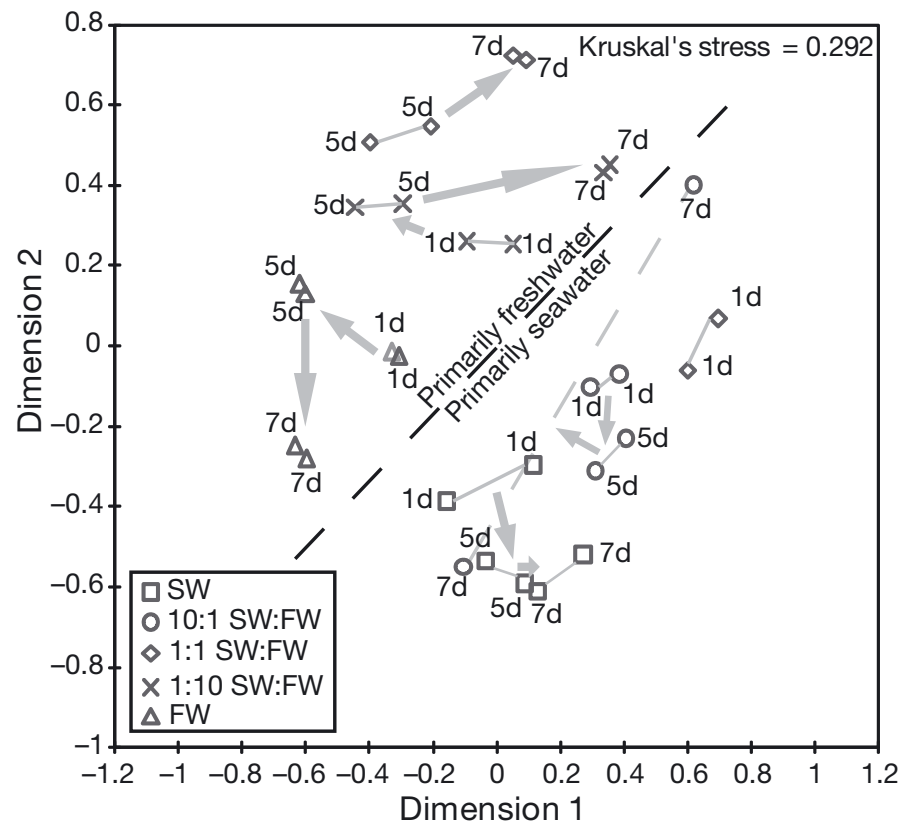

Fig. 3. Similarity of automated rRNA intergenic spacer analysis fingerprint based on the Whittaker index. Fingerprints were clustered by non-metric multidimensional scaling using an absolute model and 5 repetitions. Treatments are coded by symbols. FW: freshwater; SW: seawater. Replicate fingerprints within each treatment and timepoint (1 to $7 \mathrm{~d}$ of incubation) are connected by lines. Arrows indicate trajectory between timepoints. The 2 replicates for T7 (i.e. 7 d) 10:1 SW:FW are connected by a broken line for clarity. The trajectory is not indicated for the 1:1 SW:FW incubations between 1 and $5 \mathrm{~d}$. The length of arrows corresponds to the magnitude of change in the composition of the bacterial communities

predominately SW assemblages by the Whittaker index, which considers the relative proportion of amplified DNA associated with each OTU, suggests that dominant bacteria drive much of the similarity based on the endmember inocula.

A key question in microbial ecology is whether similar habitats give rise to similar assemblages of microorganisms (Baas-Becking 1934, Fuhrman 2002). Previous studies have indicated habitatdistinct profiles of bacterial assemblages in particleattached vs. free-living, depth and estuarine zone comparisons (Moeseneder et al. 2001, Stepanauskas et al. 2003, Hewson \& Fuhrman 2004, 2006b, Hewson et al. 2006a). A spatially extensive survey of bacterioplankton composition in the open ocean using distance-decay of similarity approaches found heterogeneity in compositions on spatial scales of 1 to $50 \mathrm{~km}$, which was consistent with physicochemical feature variation (Hewson et al. 2006b), a result confirmed by metagenomic analyses (Rusch et al. 2007). Similarly, assemblages of sediment bacteria were consistent among habitats sharing gross geological features yet were distinct among habitats (Hewson et al. 2007).

The data from this experiment indicate that observations of mixing zones of assemblages between habitats in rivers, river plumes and estuaries may be temporally dynamic. We found that the majority of taxa that respond favorably to confluence of habitats are initially rare. This demonstrates that potentially rare and weedy taxa are those that may initially respond to changed conditions because they are capable of exploiting resources that are limiting under endmember conditions. Thus, rarer taxa also contribute to much of the variability observed between replicate treatments, which in nature may cause spatial heterogeneity between assemblage compositions. Furthermore, salinity appears to play a key role as a determinant of success under mixed conditions; rarer marine taxa are more capable of success in freshwater habitats than freshwater taxa in marine habitats.

\section{Potential biases of fingerprinting approaches}

Our conclusions rely on the microbial assemblage fingerprinting approach ARISA, which characterizes OTUs based on 16S-23S rRNA intergenic spacer length (ITS) heterogeneity. While ITS length is mostly consistent with phylogeny on the genera scale (Brown et al. 2005), there may be overlap among the ITS lengths from disparate taxonomic groups. Bacteria may also contain more than a single copy of the rRNA ITS region, which may be of different lengths (Klappenbach et al. 2000). This is particularly the case with fast-growing, less nutrient-limited bacterioplankton taxa; in our experiment, some of the richness observed in freshwater bacterioplankton may have resulted from the presence of taxa with multiple rRNA copies. Because we standardized the template DNA amount and the amount of DNA run per fingerprint, our results do not reflect unequal coverage of bacterial communities. We pre-filtered our samples to eliminate plastids; however, it is possible that microeukaryotes may have made it through our pre-filter and appear as OTUs within fingerprints. Archaea are not included in our analyses nor are bacterial taxa with non-syntenous 16S-23S rRNA, like some Planctomyces and Chloroflexi. However, these potential biases do not affect our conclusions of the dominance of assemblage components responsive to habitat confluence and greater consistency among faster-growing assemblages. 


\section{CONCLUSIONS}

The results of this study demonstrate the dynamic nature of microbial assemblages in response to habitat variation. We found that rarer OTUs are more responsive to habitat confluence than dominant components of salt- and freshwater communities, and consequently, over longer timescales, habitat confluence selects for assemblages that are dominated by OTUs that are initially rare. Rare components of marine assemblages, which may be limited by prevailing conditions or represent brackish-adapted taxa at low concentrations of SW inoculum, may respond rapidly to new resource pools and be more tolerant to variable osmotic conditions than freshwater bacteria, despite presumably stronger genome streamlining in marine than freshwater habitats due to greater resource limitation. These data raise interesting questions about the fate of bacteria that are stimulated by confluent conditions within the food web, for example, their consumption by bacterivores and interactions with viral communities of the destination water mass.

Acknowledgements. The authors are grateful to K. Wells, K. Jerram, and the entire staff of the Shoals Marine Laboratory, Appledore Island, for their assistance in this study and W. Bemis, Director of Shoals, for facilitating this work. We thank J. Simonis, C. Kearns and N. Hairston for assistance with chl a fluorometry, and R. Ley, L. Angenent, E. Madsen and E. Angert for helpful conversation on the study topic. This work was supported by National Science Foundation grants OCE0961894, OCE-1049670 and DEB-1028898, Federal Formula Funds grant NYS-189489 and the Cornell Biogeochemistry and Environmental Biocomplexity Initiative.

\section{LITERATURE CITED}

Andersson AF, Riemann L, Bertilsson S (2010) Pyrosequencing reveals contrasting seasonal dynamics of taxa within Baltic Sea bacterioplankton communities. ISME J 4: $171-181$

> Azam F, Fenchel T, Field JG, Gray JS, Meyerreil LA, Thingstad F (1983) The ecological role of water-column microbes in the sea. Mar Ecol Prog Ser 10:257-263

Baas-Becking L (1934) Geobiologie of Inleiding Tot de Milieukunde. W.P. van Stockum \& Zoon N.V., Den Haag

> Bonilla-Findji O, Rochelle-Newall E, Weinbauer MG, Pizay MD, Kerros ME, Gattuso JP (2009) Effect of seawaterfreshwater cross-transplantations on viral dynamics and bacterial diversity and production. Aquat Microb Ecol $54: 1-11$

> Bouvier TC, del Giorgio PA (2002) Compositional changes in free-living bacterial communities along a salinity gradient in two temperate estuaries. Limnol Oceanogr 47: 453-470

Brown MV, Schwalbach MS, Hewson I, Fuhrman JA (2005) Coupling 16S-ITS rDNA clone libraries and ARISA to show marine microbial diversity: development and application to a time series. Environ Microbiol 7:1466-1479

Cottrell MT, Kirchman DL (2000) Natural assemblages of marine Proteobacteria and members of the CytophagaFlavobacter cluster consuming low- and high-molecularweight dissolved organic matter. Appl Environ Microbiol 66:1692-1697

Crump BC, Hopkinson CS, Sogin ML, Hobbie JE (2004) Microbial biogeography along an estuarine salinity gradient: combined influences of bacterial growth and residence time. Appl Environ Microbiol 70:1494-1505

> Ducklow HW (1983) Production and fate of bacteria in the oceans. Bioscience 33:494-501

Fisher MM, Triplett EW (1999) Automated approach for ribosomal intergenic spacer analysis of microbial diversity and its application to freshwater bacterial communities. Appl Environ Microbiol 65:4630-4636

Fuhrman JA (2002) Community structure and function in prokaryotic marine plankton. Antonie van Leeuwenhoek 81:521-527

Giovannoni S, Stingl U (2005) Molecular diversity and ecology of microbial plankton. Nature 437:343-348

Herlemann DP, Labrenz M, Jurgens K, Bertilsson S, Waniek JJ, Andersson AF (2011) Transitions in bacterial communities along the $2000 \mathrm{~km}$ salinity gradient of the Baltic Sea. ISME J 5:1571-1579

> Hewson I, Fuhrman JA (2004) Richness and diversity of bacterioplankton species along an estuarine gradient in Moreton Bay, Australia. Appl Environ Microbiol 70: 3425-3433

Hewson I, Fuhrman JA (2006a) Improved strategy for comparing microbial assemblage fingerprints. Microb Ecol 51:147-153

> Hewson I, Fuhrman JA (2006b) Spatial and vertical biogeography of coral reef sediment bacterial and diazotroph communities. Mar Ecol Prog Ser 306:79-86

Hewson I, Capone DG, Steele JA, Fuhrman JA (2006a) Influence of the Amazon and Orinoco offshore surface water plumes on oligotrophic bacterioplankton diversity in the west tropical Atlantic. Aquat Microb Ecol 43:11-22

> Hewson I, Steele JA, Capone DG, Fuhrman JA (2006b) Temporal and spatial scales of variation in bacterioplankton assemblages of oligotrophic surface waters. Mar Ecol Prog Ser 311:67-77

> Hewson I, Jacobson-Meyers M, Fuhrman J (2007) Diversity and biogeography of bacterial assemblages in surface sediments across the San Pedro Basin, Southern California Borderlands. Environ Microbiol 9:923-933

Kan J, Evans SE, Chen F, Suzuki MT (2008) Novel estuarine bacterioplankton in rRNA operon libraries from the Chesapeake Bay. Aquat Microb Ecol 51:55-66

> Kisand V, Andersson N, Wikner J (2005) Bacterial freshwater species successfully immigrate to the brackish water environment in the northern Baltic. Limnol Oceanogr 50:945-956

- Klappenbach JA, Dunbar JM, Schmidt TM (2000) rRNA operon copy number reflects ecological strategies of bacteria. Appl Environ Microbiol 66:1328-1333

Lamy D, Obernosterer I, Laghdass M, Artigas LF and others (2009) Temporal changes of major bacterial groups and bacterial heterotrophic activity during a Phaeocystis globosa bloom in the eastern English Channel. Aquat Microb Ecol 58:95-107

Lebaron P, Servais P, Troussellier M, Courties C and others (2001) Microbial community dynamics in Mediterranean 
nutrient-enriched seawater mesocosms: changes in abundances, activity and composition. FEMS Microbiol Ecol 34:255-266

Logares R, Brate J, Heinrich F, Shalchian-Tabrizi K, Bertilsson $S$ (2010) Infrequent transitions between saline and fresh waters in one of the most abundant microbial lineages (SAR11). Mol Biol Evol 27:347-357

Lozupone CA, Knight R (2007) Global patterns in bacterial diversity. Proc Natl Acad Sci USA 104:11436-11440

Maranger R, Bird DF (1995) Viral abundance in aquatic systems: a comparison between marine and fresh waters. Mar Ecol Prog Ser 121:217-226

Methe BA, Hiorns WD, Zehr JP (1998) Contrasts between marine and freshwater bacterial community composition: analyses of communities in Lake George and six other Adirondack lakes. Limnol Oceanogr 43:368-374

Moeseneder MM, Winter C, Herndl GJ (2001) Horizontal and vertical complexity of attached and free-living bacteria of the eastern Mediterranean Sea, determined by 16S rDNA and 16S rRNA fingerprints. Limnol Oceanogr 46:95-107

Morris RM, Rappé M, Connon SA, Vergin KL, Siebold WA, Carlson CA, Giovannoni SJ (2002) SAR11 clade dominated ocean surface bacterioplankton communities. Nature 420:806-810

Oren A (2001) The bioenergetic basis for the decrease in metabolic diversity at increasing salt concentrations: implications for the functioning of salt lake ecosystems. Hydrobiologia 466:61-72

Parsons TR, Maita Y, Lalli CM (1985) A manual of chemical and biological methods for seawater analysis, Vol 1. Pergamon Press, Oxford

Editorial responsibility: Josep Gasol, Barcelona, Spain
Pomeroy LR (1974) The ocean's food web: a changing paradigm. Bioscience 24:499-504

> Porter KG, Feig YS (1980) The use of DAPI for identifying and counting aquatic microflora. Limnol Oceanogr 25: 943-948

Riemann L, Leitet C, Pommier T, Simu K, Holmfeldt K, Larsson U, Hagstrom A (2008) The native bacterioplankton community in the central Baltic sea is influenced by freshwater bacterial species. Appl Environ Microbiol 74: 503-515

> Rochelle-Newall EJ, Pizay MD, Middleburg JJ, Boschker HTS, Gattuso JP (2004) Degradation of riverine dissolved organic matter by seawater bacteria. Aquat Microb Ecol $37: 9-22$

Rusch D, Halpern A, Sutton G, Heidelberg K and others (2007) The Sorcerer II Global Ocean Sampling expedition: Northwest Atlantic through Eastern Tropical Pacific. PLoS Biol 5:398-431

Stepanauskas R, Moran MA, Bergamaschi BA, Hollibaugh JT (2003) Covariance of bacterioplankton composition and environmental variables in a temperate delta system. Aquat Microb Ecol 31:85-98

- Torsvik V, Ovreas L, Thingstad TF (2002) Prokaryotic diversity - magnitude, dynamics and controlling factors. Science 296:1064-1066

Zwart G, Hiorns WD, Methe BA, Van Agterveld MP and others (1998) Nearly identical 16S rRNA sequences recovered from lakes in North America and Europe indicate the existence of clades of globally distributed freshwater bacteria. Syst Appl Microbiol 21: 546-556

Submitted: November 1, 2011; Accepted: December 9, 2011 Proofs received from author(s): March 9, 2012 